\title{
Effect of replacement of soybean meal with protected or common urea on the carcass and meat characteristics of confined steers
}

\section{Substituição do farelo de soja por ureia protegida ou comum sobre as características de carcaça e da carne de novilhos confinados}

\author{
Gilmar dos Santos Cardoso ${ }^{1 *}$; Leonel da Silva Rodrigues ${ }^{1}$; Diego Soares Machado ${ }^{1}$; \\ Camille Carijo Domingues ${ }^{1}$; Mauren Burin da Silva ${ }^{1}$; Patrícia Machado Martini \\ Cattelam²; Sander Martinho Adams²; Daniele Borchate²; Ivan Luiz Brondani³; Dari \\ Celestino Alves Filho ${ }^{3}$
}

\begin{abstract}
The objective of this study was to evaluate the effect of crude protein substitution of soybean meal with urea (slow-release or otherwise) on the carcass and the meat characteristics of finished steers in confinement. Twenty-seven castrated, purebred and Charolais-Nelore crossbred steers with a mean age of $20 \pm 1,5$ months and initial mean live weight of $293 \pm 31 \mathrm{~kg}$, were distributed in three treatments: Protected Urea (concentrate containing slow degradation urea ); Soybean meal (concentrate containing soybean meal) and Urea Common (concentrate containing common urea). A randomized block experimental design (racial predominance) was used, with three treatments and nine replications, with the animal as the experimental unit. Feeding treatments did not influence the hot and cold carcass weight and yield. The fat thickness that covered the carcass was not altered, according to the diets studied, being on average $3.97 \pm 0.94 \mathrm{~mm}$. The measurements and the carcass compactness were not altered by the diets, presenting average values of $127.55 ; 74.86 ; 39.86 ; 38.84$ and $25.72 \mathrm{~cm}$ for carcass length, leg and arm, arm perimeter and cushion thickness, respectively. A significant difference was observed in marbling, and the meat of the animals treated with soybean meal were higher than those treated with protected urea ( 3.72 vs 2.28 points).
\end{abstract}

Key words: Compactness. Primary cuts. Fat thickness. Marbling. Texture.

\section{Resumo}

O objetivo do presente estudo foi avaliar o efeito da substituição total do farelo de soja por ureia protegida ou comum sobre as características de carcaça e da carne de novilhos terminados em confinamento. Utilizaram-se 27 novilhos, puros e mestiços Charolês x Nelore, com idade de $20 \pm(1,5)$ meses e peso médio inicial de $293 \pm$ (31) $\mathrm{kg}$, distribuídos em três tratamentos: Ureia Protegida (concentrado contendo ureia de degradação lenta); Farelo de Soja (concentrado contendo farelo de soja) e Ureia Comum (concentrado contendo ureia comum). O delineamento experimental utilizado foi o de blocos ao acaso (predominância racial), com três tratamentos e nove repetições, sendo o animal a unidade

\footnotetext{
${ }^{1}$ Discentes de Doutorado, Programa de Pós-graduação em Zootecnia, Universidade Federal de Santa Maria, UFSM, Santa Maria, RS, Brasil. E-mail: cardoso-gilmar@bol.com.br; rodrigues_leonel@hotmail.com; dsoaresmachado@ymail.com; camidomingues@gmail.com; maurenburin@hotmail.com

2 Discentes de Mestrado, Programa de Pós-graduação em Zootecnia, UFSM, Santa Maria, RS, Brasil. E-mail: patriciammartini@ hotmail.com; sander.adams@hotmail.com; danieleborcharte@gmail.com

$3 \operatorname{Prof}^{\text {os }} \operatorname{Dr}^{\text {os }}$, Departamento de Zootecnia, UFSM, Santa Maria, RS, Brasil. E-mail: ivanbrondani@gmail.com; darialvesfilho@ hotmail.com

Author for correspondence
} 
experimental. Os tratamentos alimentares não influenciaram nos pesos e rendimentos de carcaça quente e fria. A espessura de gordura que recobre a carcaça não foi alterada, de acordo com as dietas estudadas, sendo em média de $3,97 \pm(0,94) \mathrm{mm}$. As medidas e a compacidade da carcaça não foram alteradas pelas dietas, apresentando valores médios de 127,55; 74,86; 39,86; 38,84 e 25,72 cm para comprimento de carcaça, perna e braço, perímetro de braço e espessura de coxão, respectivamente. Observou-se diferença significativa no marmoreio, sendo que a carne dos animais do tratamento farelo de soja foram superiores aos do tratamento com ureia protegida ( 3,72 vs 2,28 pontos).

Palavras-chave: Compacidade. Cortes primários. Espessura de gordura. Marmoreio. Textura.

\section{Introduction}

Due to the increasing consumption of beef in Brazil and in the world, rural producers are increasingly seeking better alternative methods to produce carcasses that meet the requirements of the meat industry.

In order to produce animals with better carcasses, the use of confinement during the finishing period is an important tool that can be used to improve carcass quality. It is associated with the slaughter weight used in commercialization, especially with regard to fat deposition in the carcass (ARBOITTE et al., 2004; CRUZ et al., 2004; RESTLE et al., 1997). Moreover, confinement serves to intensify production in small areas and releases pastures that can be used by other more demanding categories, especially in the reproducing phase, thus helping animals to enter the finishing phase sooner and consequently, increasing the capital turnover in the property.

The substitution of true protein sources with non-protein nitrogen (NPN) has emerged as an alternative way to reduce production costs (PAIXÃO et al., 2006). Protein foods are the most expensive in the diet and their use results in higher cost in the cattle finishing; this is especially true for soybean meal, because it has good protein content and high biological value. Thus, the substitution of protein sources could not only reduce dietary costs, but also contribute to nutritional factors needed to maintain carcass and meat characteristics.

Ammonia is the main compound required for rumen protein synthesis. Ammonia is used to great extent by fibrous carbohydrate fermenting bacteria as a source of nitrogen for the development of ruminal microorganisms and microbial protein production (PAULA et al., 2009). Thus, urea is the most common ingredient for the supply of NPN, which contributes to the formation of ammoniacal nitrogen to meet microbial requirements. The use of slow release urea (Optigen) may be a suitable option in the total or partial substitution of nitrogen as a source of protein, since the slow release shows that the ruminal hydrolysis of this product is cadenced and favors the synchronization between fibber degradation and the release of nitrogen to fibrolytic bacteria (BENEDETI et al., 2014; RIBEIRO et al., 2011).

The objective of this study was to evaluate the effect of crude protein substitution of soybean meal with urea (slow-release or otherwise) on the carcass and the meat characteristics of finished steers in confinement.

\section{Material and Methods}

The experiment was carried out from August to December 2014 at the Laboratório de Bovinocultura de Corte (LBC), belonging to the Department of Animal Science of the Federal University of Santa Maria, located in the municipality of Santa Maria, Rio Grande do Sul.

Twenty-seven castrated, purebred and CharolaisNelore crossbred steers with a mean age of $20 \pm$ $(1,5)$ months and initial mean live weight of $293 \pm$ (31) $\mathrm{kg}$ were used in the experiment. All the animals used in the study were from the experimental herd of the LBC. 
The animals were confined in covered and paved $12 \mathrm{~m}^{2}$ boxes. Each box has a trough. Drinking fountains were shared between two boxes. The water was supplied ad libitum with level regulated by a float valve faucet. Before the experimental period, the steers were adapted to the experimental conditions for 20 days. In addition to the adaptation, the control of endoparasites was also carried out with the application of an albendazole sulfoxidebased product ( $10 \%$ concentration).
The rations were calculated as previously detailed (NRC, 2000), with an estimated intake of dry matter (DM) of $2.65 \mathrm{~kg} 100 \mathrm{~kg}^{-1}$ live weight (LW) and an average daily weight gain of $1.5 \mathrm{~kg}$ per animal with an isonitrogenated ration (Table 1). The steers were distributed according to the predominance of genetics and balanced by LW to concentrates containing slow-release urea, soybean meal, or agricultural urea.

Table 1. Participation of ingredients and chemical composition of the experimental rations.

\begin{tabular}{|c|c|c|c|}
\hline \multirow{2}{*}{ Ingredients } & \multicolumn{3}{|c|}{ Treatments } \\
\hline & Slow-release urea & Soybean meal & Agricultural urea \\
\hline${ }^{1}$ Corn silage (\%) & 35.00 & 35.00 & 35.00 \\
\hline${ }^{2}$ Corn $(\%)$ & 45.37 & 35.94 & 45.35 \\
\hline${ }^{2}$ Oat grain $(\%)$ & 16.25 & 16.25 & 16.25 \\
\hline${ }^{2}$ Soybean meal (\%) & -- & 11.05 & -- \\
\hline${ }^{2}$ Urea $(\%)$ & 1.75 & -- & 1.72 \\
\hline${ }^{2}$ Calcitic limestone $(\%)$ & 0.97 & 1.10 & 0.97 \\
\hline \multirow[t]{2}{*}{${ }^{2}$ Mineral salt (\%) } & 0.65 & 0.65 & 0.65 \\
\hline & \multicolumn{3}{|c|}{ Chemical composition } \\
\hline${ }^{1}$ Dry matter $(\%)$ & 64.82 & 66.41 & 64.80 \\
\hline${ }^{1}$ Crude protein $(\%$ of DM) & 14.35 & 14.88 & 14.70 \\
\hline${ }^{1}$ Ether extract $(\%$ of DM) & 3.37 & 3.20 & 3.37 \\
\hline${ }^{1}$ Mineral matter ( $\%$ of DM) & 2.42 & 3.02 & 2.42 \\
\hline${ }^{1}$ Neutral detergent fiber ( $\%$ of DM) & 25.88 & 26.60 & 25.87 \\
\hline${ }^{1}$ Total digestible nutrient $(\%$ of $\mathrm{DM})$ & 77.24 & 77.34 & 77.22 \\
\hline
\end{tabular}

${ }^{1}$ Participation in composition of total ration; ${ }^{2}$ Participation in concentrated fraction.

The ration was supplied in two meals, with half in the morning at $08 \mathrm{~h} 00$ and the rest in the afternoon at $14 \mathrm{~h} 00$. The slow-release and agricultural urea rations were weighed separately and added to the troughs and then mixed thoroughly with the other ingredients. The voluntary intake of the ration was recorded daily by weighing the quantity of food offered and the leftover food from the previous day to calculate the consumption of dry matter. The food leftovers were pre-established to be between $5 \%$ and $8 \%$ higher than the daily consumption of the previous day. The rations offered in the slow- release urea, soybean meal, and agricultural urea treatment provided an average daily gain of 1.560; 1.716 , and $1.536 \mathrm{~kg}$; dry matter intake of $2.37 ; 2.08$, and $2.36 \%$, and feed conversion of $6.12 ; 5.00$, and 6.49 respectively.

When the steers reached a weight of $450 \mathrm{~kg}$ as a predetermined average for slaughter, the animals were slaughtered in a commercial slaughterhouse, following the normal flow of the establishment. The animals were slaughtered in two lots. In the first lot, 15 animals were sent, comprising five animals of each treatment with the balanced genetic groups 
remaining 91 days in the feedlot. After 11 days, the remaining 12 animals were sent to the second slaughter, comprising four of each treatment with 102 days of confinement. Before the slaughter, the animals were weighed following a 14-hour fast for solids and liquids.

After slaughter, the carcasses were divided with an electric saw in two halves (right half carcass and left half carcass), washed, identified, weighed, and conditioned in a cold room for 24 hours. At the end of the cooling, they were again weighed to determine the hot and cold carcass weight, the hot and cold carcass yield, and the loss due to cooling.

Carcasses were evaluated for conformation and physiological maturity, according to the methodology of Müller (1987). The left half carcasses were separated into primal cuts: forequarter, ribs (short ribs) and pistol (hind), and were weighed to determine their share of cold carcass weight. The evaluation of the physiological maturity was performed based on the degree of ossification of the cartilages present in the spinal processes of the thoracic and lumbar vertebrae, and between the sacral vertebrae (MÜLLER, 1987).

In the right half carcass, the following measurements were taken: carcass length (distance between the medial cranial edge of the first rib and pubic bone border); leg length (distance between the anterior pubic bone edge and the midpoint of tibio-tarsal join); round thickness (distance between the lateral side and the medial side of the upper portion of the round); arm length (distance between the tuberosity of the olecranon and the radio-carpal joint); and the perimeter of the arm (measured in the medial region).

In the right half carcass of each animal, a cross section was performed on the Longissimus dorsi muscle between the $12^{\text {th }}$ and $13^{\text {th }}$ ribs with the purpose of removing a portion called the "HH section", between the $10^{\text {th }}$ and $12^{\text {th }}$ ribs, according to the methodology proposed by Hankins and Howe (1946) and later adapted by Müller (1973), aiming to expose the Longissimus dorsi muscle. In this same section, the measurement of the loin eye area was performed contouring the muscle in vegetal paper, and digitized later to determine its areas. The subcutaneous fat thickness, obtained by the average of three measurements, was also evaluated in this section. After 30 minutes of exposure of the muscle to air, evaluations of marbling, color, and texture of the meat were performed, according to Müller (1987).

Once all the qualitative evaluations were performed, the samples were taken to the LBC meat laboratory, and the physical separation was carried out in order to determine the percentages of muscle, bone, and fat, using Hankins and Howe equations (1946). The Longissimus dorsi muscles were vacuum packed in brown paper, identified, and frozen for further analysis of sensory characteristics. Two slices (A and B) with a thickness of $2.5 \mathrm{~cm}$ were removed from the frozen samples and the loss of liquid by thawing in a refrigerator for 24 hours was determined. After thawing, the steaks were cooked in a preheated electric oven at a temperature of 300 ${ }^{\circ} \mathrm{C}$ for approximately 15 minutes, turning the sides every 7.5 minutes, until the internal temperature reached $70{ }^{\circ} \mathrm{C}$.

The steak " $A$ " was used to evaluate the losses due to cooking (weight before and after cooking) and to evaluate the resistance of the fibers to the cut, through the texturometer apparatus, whose result was the arithmetic average of six readings per steak with fiber bundles of $1 \mathrm{~cm}^{3}$ (MÜLLER, 1987). The steak "B" was utilized to determine the tenderness, palatability, and succulence by a panel of six trained tasters, according to the methodology of Müller (1987).

A randomized block experimental design (racial predominance) was used, with three treatments and nine replications, with the animal as the experimental unit. The variables were tested for normality by the Shapiro-Wilk test. The data were submitted to analysis of variance by $\mathrm{F}$ test with $5 \%$ significance, 
using the PROC GLM. For the variables that showed a difference, the averages were compared by the Student's t-test with 5\% significance, using the Statistical Analysis System, version 9.4 (SAS INSTITUTE, 2001). The mathematical model adopted in the analysis of variance was

$$
\mathrm{Y}_{\mathrm{ij}}=\mu+\beta \mathrm{i}+\mathrm{T}_{\mathrm{j}}+\varepsilon_{\mathrm{ij}}
$$

where $\mathrm{Y}_{\mathrm{ij}}=$ dependent variables, $\mu=$ means of all observations, $\beta \mathrm{i}=$ effect of the $\mathrm{i}^{\text {th }}$ block corresponding to the genetic predominance of the animal, $\mathrm{T}_{\mathrm{j}}=$ effect of the $\mathrm{j}^{\text {th }}$ treatment, and $\varepsilon_{\mathrm{ij}}=$ residual random error. Pearson's correlation test was also performed using the PROC CORR procedure.

\section{Results and Discussion}

Feeding treatments did not influence $(\mathrm{P}>$ $0.05)$ the hot and cold carcass weight and yield (Table 2), and the similarity occurred due to the similar slaughter weight pre-established before the experimental period. Several factors influence the carcass yield, such as diet, age, race, sex, and washing in the slaughter line (BRONDANI et al., 2004). A similar result was found by Gleghorn et al. (2004), who did not observe any effect on the hot carcass weight when cotton meal was replaced with urea. Mascardi (2009) also found no difference in carcass weight and yield with or without protected urea (Optigen $\left.{ }^{\circledR}\right)$ in the animals' diet. Tedeschi et al. (2002) also did not find differences with respect to the diet containing urea, when analyzing the diets of steers in the finishing phase. According to Menezes et al. (2005), carcass yield characteristics have become very important in recent years for the production system, since initially the cattle were marketed based on live weight, but currently the commercialization is based on the carcass weight, mainly hot carcass.

Table 2. Slaughter and hot and cold carcass weight, and hot and cold carcass yield of steers treated with protected urea or common urea instead of soybean meal.

\begin{tabular}{|c|c|c|c|c|c|}
\hline \multirow{2}{*}{ Variables } & \multicolumn{3}{|c|}{ Treatments } & \multirow{2}{*}{ SEM } & \multirow{2}{*}{ P-value } \\
\hline & Protected urea & Soybean meal & Common urea & & \\
\hline Slaughter weight, kg & 450.26 & 462.54 & 455.04 & 23.24 & 0.6269 \\
\hline Hot carcass weight, $\mathrm{kg}$ & 257.32 & 270.70 & 261.39 & 12.91 & 0.7045 \\
\hline Cold carcass weight, $\mathrm{kg}$ & 252.16 & 265.28 & 256.03 & 12.65 & 0.7056 \\
\hline Hot carcass yield, $\%$ & 57.18 & 58.51 & 57.44 & 0.62 & 0.7024 \\
\hline Cold carcass yield, $\%$ & 55.92 & 57.33 & 56.26 & 0.62 & 0.7110 \\
\hline
\end{tabular}

$\mathrm{SEM}=$ standard error of the mean.

It was observed that the fat thickness (Table 3) covering the carcass was not altered $(\mathrm{P}>0.05)$, according to the diets studied, which could be related to the similarity in the energy levels of the diets. On average, the cover fat thickness was $3.97 \pm$ $0.94 \mathrm{~mm}$, which is within the limits required by the slaughterhouse industry, which recommends that the carcasses be between 3 and $6 \mathrm{~mm}$ of fat thickness. The evaluation of cover or subcutaneous fat is accepted internationally as an indicator of carcass fat (LUCHIARI FILHO, 2000). This variable has substantial influence on the characteristics of the carcass, as it serves as thermal insulation and protects the carcass against loss of liquids during the cooling process. In addition, it also helps avoid shortening of muscle fibers and darkening caused by cold, which causes problems in the visual aspect of the meat, decreasing the preference by the consumer.

Losses due to the cooling of the carcasses was 
similar between the treatments $(\mathrm{P}>0.05)$, which is due to the similarity in the cover fat thickness. This variable determines the weight loss of the carcass in the form of water during the cooling period. Average values were observed in percentages of
2.00, 1.99, and 2.05 for samples from animals fed with diets containing protected urea, soybean meal, or common urea, respectively. According to Pacheco et al. (2005), the loss due to the cooling is negatively associated with subcutaneous fat thickness.

Table 3. Fat thickness, loss due to cooling, Longissimus dorsi area, conformation, and physiological maturity of steers treated with protected urea or common urea instead of soybean meal.

\begin{tabular}{|c|c|c|c|c|c|}
\hline \multirow{2}{*}{ Variables } & \multicolumn{3}{|c|}{ Treatments } & \multirow{2}{*}{ SEM } & \multirow{2}{*}{ P-value } \\
\hline & Protected urea & Soybean meal & Common urea & & \\
\hline Fat thickness, mm & 3.65 & 4.46 & 3.80 & 0.63 & 0.9124 \\
\hline Loss due to cooling, $\%$ & 2.00 & 1.99 & 2.05 & 0.02 & 0.7184 \\
\hline Longissimus dorsi area, $\mathrm{cm}^{2}$ & 70.51 & 74.76 & 69.65 & 2.23 & 0.7783 \\
\hline Conformation, score ${ }^{1}$ & 10.99 & 10.66 & 10.88 & 0.28 & 0.4296 \\
\hline Physiological maturity, score ${ }^{2}$ & 12.58 & 12.58 & 12.46 & 0.16 & 0.7758 \\
\hline
\end{tabular}

${ }^{1} 1-3=$ inferior; 4-6 = bad; 7-9 = regular; $10-12=$ good; $13-15=$ very good; $16-18=$ superior.

${ }^{2} 1-3$ = above 8 years old; $4-6=$ from 5.5 to 8 years old; $7-9=$ from 4 to 5.5 years old; $10-12=$ from 2.5 to 4 years old; $13-15=$ below 2.5 years old.

$\mathrm{SEM}=$ standard error of the mean.

The Longissimus dorsi area was not affected by the diets to which the animals were subjected (Table 3). The carcasses presented average values of $71.64 \mathrm{~cm}^{2}$ of area, a result superior to those of Andrighetto et al. (2009), who stated that values between 66 and $69 \mathrm{~cm}^{2}$ are indicative of good yield of meat cuts. For this variable, there was a correlation with the slaughter weight, $0.57(\mathrm{P}=$ 0.0016), corroborating with Cattelam et al. (2013), who also found a directly proportional correlation ( $\mathrm{r}$ $=0.71 ; \mathrm{P}<0.0001)$ between the Longissimus dorsi area and the slaughter weight. The loin eye area (LEA) is an important characteristic to be observed, since it is related to the muscularity of cuts of high commercial yield (LUCHIARI FILHO, 2000).

The similarity can also be observed in the conformation, which expresses the degree of carcass muscularity and contributes beneficially to its yield. In the present study, the carcasses presented an average conformation of 10.84 points and were classified as "good". For Santos et al. (2008), carcasses with better conformation are preferred by slaughterhouses and butcher shops, since they are associated with greater muscle hypertrophy and higher meat yield at deboning. The physiological maturity also did not differ between the animals subjected to the different treatments $(\mathrm{P}>0.05)$, classifying the animals of the study in physiological maturity ranging from 2.5 to 4 years of age. This feature is related to the degree of ossification of the cartilages of the spinal processes of the thoracic vertebrae and the degree of fusion of the sacral vertebrae.

The absolute weight and yield of the primary commercial cuts were not influenced by the $\mathrm{N}$ sources studied (Table 4), due to the similarity in slaughter and cold carcass weights. Correlations were observed between slaughter weights in forequarter $(\mathrm{r}=0.91)$, ribs $(\mathrm{r}=0.90)$, and hindquarter $(\mathrm{r}=0.95)$, all with $\mathrm{P}<0.0001$. These values were similar to those found by the report by Roman et al. (2010), which evaluated the physical composition of the carcass of confined beef cattle subjected to isoprotein and isoenergetic diets $(14 \%$ of $\mathrm{PB}$ and 
$70 \%$ of NDT) and found averages values of 39.1, 48.4 , and $12.8 \%$ for the proportions of forequarter, hindquarter, and short ribs, respectively, which did not differ between treatments. Vaz and Restle (2001) emphasized that the greater participation of the ribs is mainly related to the weight and finishing of the carcass, due to the deposition of fat in this cut. According to Brondani et al. (2004), this cut is of greater interest in regional cooking in Rio Grande do Sul and highly appreciated in the preparation of roasts.

Table 4. Absolute weights and yields of commercial carcass cuts of steers treated with protected urea or common urea instead of soybean meal.

\begin{tabular}{lccccc}
\hline \multirow{2}{*}{ Variables } & \multicolumn{3}{c}{ Treatments } & \multirow{2}{*}{ SEM } & P-value \\
\cline { 2 - 4 } & Protected urea & Soybean meal & Common urea & & \\
\hline Forequarter, kg & 47.19 & 49.14 & 48.71 & 2.50 & 0.8781 \\
Forequarter, \% & 37.41 & 37.05 & 38.14 & 0.30 & 0.2433 \\
Ribs, kg & 14.02 & 15.99 & 14.92 & 0.74 & 0.4091 \\
Ribs, \% & 11.11 & 12.07 & 11.61 & 0.21 & 0.2836 \\
Hindquarter, kg & 64.58 & 67.80 & 64.57 & 2.41 & 0.5003 \\
Hindquarter, \% & 51.28 & 51.14 & 50.43 & 0.76 & 0.9174 \\
\hline
\end{tabular}

SEM $=$ standard error of the mean.

Table 5 presents the average values of the metric sizes and the carcass compactness, which were not altered by the diets $(\mathrm{P}>0.05)$, presenting average values of $127.55,74.86,39.86,38.84$, and 25.72 $\mathrm{cm}$ for carcass length, leg and arm, arm perimeter, and round thickness, respectively. The results were similar to those found by Brondani et al. (2006), who also did not observe the influence of the diets on the metric characteristics of the carcass.

Table 5. Carcass, leg, and arm length, arm perimeter, round thickness, and carcass compactness of steers treated with protected urea or common urea instead of soybean meal.

\begin{tabular}{lccccc}
\hline \multirow{2}{*}{ Variables } & \multicolumn{3}{c}{ Treatments } & \multirow{2}{*}{ SEM } & P-value \\
\cline { 2 - 4 } & Protected urea & Soybean meal & Common urea & & \\
\hline Carcass length, cm & 124.76 & 132.87 & 125.04 & 3.43 & 0.6102 \\
Leg length, cm & 74.62 & 74.90 & 75.07 & 1.12 & 0.8412 \\
Arm length, cm & 40.16 & 39.16 & 40.27 & 1.90 & 0.9904 \\
Arm perimeter, cm & 38.75 & 39.14 & 38.64 & 1.56 & 0.8039 \\
Round thickness, cm & 26.02 & 25.91 & 25.24 & 0.72 & 0.4860 \\
Compactness, $\mathrm{kg} \mathrm{cm}^{-1}$ & 2.01 & 2.03 & 2.03 & 0.07 & 0.5700 \\
\hline
\end{tabular}

$\mathrm{SEM}=$ standard error of the mean.

These characteristics are related to the slaughter weight of the animals, so the similarity of these variables is in agreement with the weight and the age of the steers. Similarly, the compactness was not affected by the ingredients tested in the diets, due to the similarity in carcass weight and length, with values equal to 2.03 for soybean meal and common urea and 2.01 for protected urea treatment. 
In this study, the amount of muscle, fat, and bone in the carcass in absolute weight and percentage were similar among the animals subjected to the different treatments (Table 6), possibly because the degree of development and finishing presented similarity, with equal rates of weight gain. Tedeschi et al. (2002) did not observe effects on carcass tissue ratios when supplementing steers in the finishing phase with urea, Optigen, or the combination thereof. Despite the low percentage of bone found in this study, no differences were observed between the treatments.
The percentage of muscle in the carcass was inversely correlated with the percentage of fat $(\mathrm{r}$ $=-0.87 ; \mathrm{P}<0.0001)$. Ribeiro et al. (2001) points out that the proportion of muscles in the carcass tends to decrease, in later stages of the life of the animal, due to the acceleration of the development of adipose tissues. The relationship between muscle mass and fat is variable, depending on the degree of finishing of the animal, which in turn depends on the breed or biotype and on the nutritional level, with the proportion of bone being less variable (Di MARCO, 2007).

Table 6. Absolute and relative weight in $100 \mathrm{~kg}$ of cold carcass of muscle, fat, and bone, and proportions between the tissues of steers treated with protected urea or common urea instead of soybean meal.

\begin{tabular}{lccccc}
\hline \multirow{2}{*}{ Variables } & \multicolumn{3}{c}{ Treatments } & \multirow{2}{*}{ SEM } & P-value \\
\cline { 2 - 4 } & Protected urea & Soybean meal & Common urea & & 0.6280 \\
Muscle, kg & 151.26 & 153.65 & 148.05 & 5.20 & 0.96 \\
Muscle, \% & 64.61 & 63.38 & 63.18 & 0.96 & 0.4552 \\
Fat, kg & 59.64 & 69.76 & 64.13 & 5.21 & 0.4610 \\
Fat, \% & 22.58 & 24.22 & 23.36 & 0.71 & 0.3007 \\
Bone, kg & 41.23 & 41.85 & 43.82 & 3.36 & 0.7650 \\
Bone, \% & 14.22 & 13.91 & 14.70 & 0.26 & 0.9345 \\
Muscle/bone ratio & 3.70 & 3.72 & 3.38 & 0.19 & 0.7642 \\
Muscle/fat ratio & 2.61 & 2.24 & 2.33 & 0.13 & 0.2358 \\
(Muscle + fat)/bone ratio & 5.20 & 5.41 & 4.86 & 0.19 & 0.9190 \\
\hline
\end{tabular}

$\mathrm{SEM}=$ standard error of the mean.

Due to the similarity found in the participation of the tissues that compose the carcass, the edible portion represented by the ratio (muscle + fat)/bone, did not present significant difference between the diets. The average value obtained for this variable was 5.15 , which is similar to that reported by Cattelam et al. (2013).

With respect to the meat coloration (Table 7), no differences were observed $(\mathrm{P}>0.05)$; however, it was classified as "slightly dark red", with an average value of 3.51 points in the animals treated with non-protein nitrogen, and in animals treated with soybean meal, the meat was classified as "red" with a value of 4.68 points. Vaz and Restle (2002) argued that meat coloration is the first assessment that the consumer makes at the time of purchase. The texture in both treatments presented identical values of 4.77 points and were classified as "fine", which may be justified by the similar age of the animals. Lawrie (2005) pointed out that among all the attributes of sensory quality, texture and tenderness are considered the most important by the average consumer.

There was a significant difference $(\mathrm{P}<0.05)$ in marbling (Table 7), which represents the deposition of intramuscular fat and contributes positively to 
the flavor and tenderness of the meat. The marbling in the meat from animals treated with soybean meal was higher than in those treated with protected urea (3.72 vs. 2.28 points) and was classified as "traces". Meat of animals treated with common urea did not differ from those of the other treatments and were classified as "traces". In order to reach this characteristic, there is order in the deposition of fat in the carcass; the first deposited fat is the intermuscular, then the greater fraction of fat of the carcass, followed by the subcutaneous and finally the intramuscular fat (PAULINO et al., 2009).

Losses due to defrosting and cooking presented similar results with respect to the different treatments $(\mathrm{P}>0.05)$, which could be related to the similarity in the subcutaneous fat thickness.
In the present study, the diets used did not influence $(\mathrm{P}>0.05)$ the organoleptic characteristics of the meat. Palatability was classified as "slightly above average" for meat of steers fed with soybean meal, with a value of 6.02 points. Meats of the other treatments were classified as "average", with values of 5.53 and 5.83 points for those from treatments with protected urea and common urea, respectively. Costa et al. (2002) emphasized that carcasses with a higher degree of finishing, marbling, and lipid content present better palatability, indicating that the fat present inside the muscle cells has palatable flavoring substances. Succulence was classified as "average" for all meats. According to Kuss et al. (2005), the higher liquid losses during cooking result in less succulent meats.

Table 7. Color, texture, marbling, loss due to cooling and cooking, organoleptic characteristics, and shearing force of steers treated with protected urea or common urea instead of soybean meal.

\begin{tabular}{|c|c|c|c|c|c|}
\hline \multirow{2}{*}{ Variables } & \multicolumn{3}{|c|}{ Treatments } & \multirow{2}{*}{ SEM } & \multirow{2}{*}{ P-value } \\
\hline & Protected urea & Soybean meal & Common urea & & \\
\hline Color, score $^{1}$ & 3.68 & 4.68 & 3.35 & 0.27 & 0.7204 \\
\hline Texture, score ${ }^{2}$ & 4.77 & 4.77 & 4.77 & 0.20 & 1.0000 \\
\hline Marbling, score ${ }^{3}$ & $2.28 \mathrm{~b}$ & $3.72 \mathrm{a}$ & $3.06 \mathrm{ab}$ & 0.43 & 0.0477 \\
\hline Loss due to cooling, $\%$ & 8.65 & 9.09 & 9.59 & 0.37 & 0.4219 \\
\hline Loss due to cooking, $\%$ & 25.66 & 26.07 & 26.25 & 1.51 & 0.9235 \\
\hline Palatability, score ${ }^{4}$ & 5.53 & 6.02 & 5.83 & 0.18 & 0.8852 \\
\hline Succulence, score ${ }^{4}$ & 5.15 & 5.94 & 5.64 & 0.21 & 0.6009 \\
\hline Tenderness, score ${ }^{4}$ & 6.14 & 6.79 & 6.04 & 0.39 & 0.6486 \\
\hline Shearing force, $\mathrm{kgF} \mathrm{cm}^{3}$ & 5.95 & 4.38 & 5.86 & 0.26 & 0.2034 \\
\hline
\end{tabular}

Averages followed by lowercase letters on the same line differ from one another by the t-test $(\mathrm{P}<0.05)$, by PROC GLM.

${ }^{1} 1=$ dark; 2 = dark red; $3=$ slightly dark red; $4=$ red; $5=$ bright red

${ }^{2} 1=$ very coarse; 2 = coarse; $3=$ slightly coarse; 4 = fine; $5=$ very fine

${ }^{3} 1$ to $3=$ traces; 4 to $6=$ light; 7 to $9=$ small; 10 and $12=$ medium; 13 to $15=$ moderate; 16 to $18=$ abundant

${ }^{4} 1$ = extremely hard, extremely flavorless or extremely without succulence; 2 = very hard, deficient in taste, or deficient in succulence; 3 = hard, not very tasty, or not very succulent; 4 = slightly below average; $5=$ average; $6=$ slightly above average; 7 $=$ soft, tasty, or succulent; $8=$ very soft, very tasty, or very succulent; $9=$ extremely soft, extremely tasty, or extremely succulent. $\mathrm{SEM}=$ standard error of the mean.

The meat tenderness, evaluated by the panel of tasters, was similar independent of the diet provided to steers. According to Barcellos (2002), the tenderness of the meat is the main organoleptic characteristic considered by the consumer. In this study, this variable had a high correlation with succulence and shearing force $(\mathrm{P}<0.001)$, with values of 0.77 and -0.73 , respectively.

The shearing force was not altered by the diets tested in this study $(\mathrm{P}>0.05)$, similar to other 
characteristics. The changes in the shearing force were closely related to the genetic group and the age of the animals, than with the type of food used in the finishing phase. According to research conducted by Koohmaraie et al. (2002), customers consider tenderness to be the most important component of meat quality. Therefore, one of the alternatives for the cattle-breeder to produce quality meat suitable for the consumer market would be to intensify its production system.

\section{Conclusions}

The use of non-nitrogen protein instead of soybean meal produces equally developed carcasses with similar proportions of commercial cuts and tissues. Animals that consumed the true protein source obtained more marbled meat compared to the meat from animals that consumed protected urea.

\section{References}

ANDRIGHETTO, C.; ARAUJO, L. C. A.; CARDASSI, M. R.; SANTOS, J.; LUPATINI, G. C.; FONSECA, R. Características da carcaça de bovinos da raça Nelore suplementados durante o período seco com sal proteinado e concentrado. In: ENCONTRO DE ZOOTECNIA, 6., 2009, Dracena. Anais... Dracena: UNESP, set. 2009. p. 22-24.

ARBOITTE, M. Z.; RESTLE, J.; ALVES FILHO, D. C.; PASCOAL, L. L.; PACHECO, P. S.; SOCCAL, D. C. Características da carcaça de novilhos 5/8 Nelore - 3/8 Charolês abatidos em diferentes estádios de desenvolvimento. Revista Brasileira de Zootecnia, Viçosa, MG, v. 33, n. 4, p. 969-977, 2004.

BARCELlOS, M. D. Processo decisório na compra de carne bovina na cidade de Porto Alegre. 2002. Dissertação (Mestrado em Agronegócio) - Centro de Estudos e Pesquisa em Agronegócios, Universidade Federal do Rio Grande do Sul, Porto Alegre.

BENEDETI,P.D.B.; PAULINO,P.V.R.; MARCONDES, M. I.; VALADARES FILHO, S. C.; MARTINS, T. S.; LISBOA, E. F.; SILVA, L. H. P.; TEIXEIRA, C. R. V.; DUARTE, M. S. Soybean meal replaced by slow release urea in finishing diets for beef cattle. Livestock Science, Viçosa, v. 165, n. 9, p. 51-60, 2014.
BRONDANI, I. L.; RESTLE, J.; ARBOITTE, M. Z.; MENEZES, L. F. G.; ALVES FILHO, D. C.; AMARAL, G. A.; PAZDIORA, R. D. Efeito de dietas que contêm cana-de-açúcar ou silagem de milho sobre as características das carcaças de novilhos confinados. Ciência Rural, Santa Maria, v. 36, n. 1, p. 197-202, 2006.

BRONDANI, I. L.; SAMPAIO, A. A. M.; RESTLE, J.; BERNARDES, R. A. L.C.; PACHECO, P. S.; FREITAS, A. K.; KUSS, F.; PEIXOTO, L. A. O. Aspectos quantitativos de carcaça de bovinos de diferentes raças, alimentados com diferentes níveis de energia. Revista Brasileira de Zootecnia, Viçosa, MG, v. 33, n. 4, p. 978988, 2004.

CATTELAM, J.; BRONDANI, I. L.; ALVES FILHO, D. C.; SEGABINAZI, L. R.; CALlegarO, A. M.; MICHELON, J. Características de carcaça e qualidade da carne de novilhos confinados em diferentes espaços individuais. Ciência Animal Brasileira, Goiânia, v. 14, n. 2, p. 185-198, 2013.

COSTA, E. C.; RESTLE, J.; VAZ, F. N.; PERETTONI, J.; FATURI, C.; MENZES, L. F. G. Composição física da carcaça. qualidade da carne e conteúdo de colesterol no músculo Longissimus dorsi de novilhos Red Angus superprecoces, terminados em confinamento e abatidos com diferentes pesos. Revista Brasileira de Zootecnia, Viçosa, MG, v. 31, n. 1, p. 417-428, 2002.

CRUZ, G. M.; TULLIO, R. R.; ESTEVES, S. N.; ALENCAR, M. M.; CORDEIRO, C. A. Peso de abate de machos não castrados para produção do bovino jovem. 2. Peso, idade e características da carcaça. Revista Brasileira de Zootecnia, Viçosa, MG, v. 33, n. 3, p. 646657, 2004.

DI MARCO, O. N.; BARCELLOS, O. J.; COSTA, E. C. Crescimento de bovinos de corte. Porto Alegre: UFRGS, 2007. $276 \mathrm{p}$.

GLEGHORN, J. F.; ELAM, N. A.; GALYEAN, M. L.; DUFF, G. C.; COLE, N. A.; RIVERA, J. D. Effects of crude protein concentration and degradability on performance, carcass characteristics, and serum urea nitrogen concentrations in finishing beef steers. Journal of Animal Science, Champaign, v. 82, n. 9, p. 2705-2717, 2004.

HANKINS, P.; HOWE, P. E. Estimation of composition of beef carcasses and cuts Technical Bulletin, 926. Washington: United States Department of Agriculture, 1946. $21 \mathrm{p}$.

KOOHMARAIE, M.; WHEELER, T. L.; SHACKELFORD, S. D. Beef tenderness: regulation and prediction. USDA-ARS U.S. Meat Animal Research Center: Clay Center, 2002. 25 p. 
KUSS, F.; RESTLE, J.; BRONDANI, I. L.; ALVES FILHO, D. C.; PEROTTONI, J.; MISSIO, R. L.; AMARAL, G. A. Composição física da carcaça e qualidade da carne de vacas de descarte de diferentes grupos genéticos terminadas em confinamento com distintos pesos. Revista Brasileira de Zootecnia, Viçosa, MG, v. 34, n. 4, p. 1285-1296, 2005.

LAWRIE, R. A. Ciência da carne. 6. ed. Porto Alegre: Artmed, 2005. 384 p.

LUCHIARI FILHO, A. Pecuária da carne bovina. São Paulo: A. Luchiari Filho, 2000. 134 p.

MASCARDI, L. E. Evaluación de Optigen ${ }^{\circledR}$ como fuente de proteína en terneros alimentados a corral. Maringá: [s.n.], 2009. Disponible en: <http://www. alltechyoungscientist.com/YSA/pt/winners.cfm>. Consultado el: 14 ago. 2017.

MENEZES, L. F. G.; RESTLE, J.; BRONDANI, I. L.; ALVES FILHO, D. C.; KUSS, F.; SILVEIRA, M. F.; AMARAL, G. A. Características da carcaça de novilhos de gerações avançadas do cruzamento alternado entre as raças Charolês e Nelore, terminados em confinamento. Revista Brasileira de Zootecnia, Viçosa, MG, v. 34, n. 3, p. 934-945, 2005.

MÜLLER, L. Normas para a avaliação de carcaças e concurso de carcaças de novilhos. 2. ed. Santa Maria: Imprensa Universitária, 1987. 31 p.

Técnicas para determinar la composición de la canal. Guadalajara: Memória de la Associación Latinoamericana de Producción Animal, 1973. 75 p.

NATIONAL RESEARCH COUNCIL - NRC. Nutrient requirements of beef cattle. $7^{\text {th }}$ ed. Washington: National Academy of Sciences, 2000. 242 p.

PACHECO, P. S.; RESTLE, J.; SILVA, J. H. S.; BRONDANI, I. L.; PASCOAL, L. L.; ALVES FILHO, D. C.; ARBOITTE, M. Z.; FREITAS, A. K. Composição física da carcaça e qualidade da carne de novilhos jovens e superjovens de diferentes grupos genéticos. Revista Brasileira de Zootecnia, Viçosa, MG, v. 34, n. 5, p. 16911703, 2005.

PAIXÃO, M. P.; VALADARES FILHO, S. C.; LEÃO, M. I.; VALADARES, R. F. D.; PAULINO, M. F.; MARCONDES, M. I.; FONSECA, M. A.; SILVA, P. A.; PINA, D. S. Ureia em dietas para bovinos: consumo, digestibilidade aparente, ganho de peso, característica da carcaça e produção microbiana. Revista Brasileira de Zootecnia, Viçosa, MG, v. 35, n. 6, p. 2451-2460, 2006.

PAULA, A. A. G. D.; FERREIRA, R. N.; ORSINE, G. F.; GUIMARÃES, L. O.; OLIVEIRA, E. R. Ureia polímero e ureia pecuária como fontes de nitrogênio solúvel no rúmen: parâmetros ruminal e plasmático. Ciência Animal
Brasileira, Goiânia, v. 10, n. 1, p. 1-8, 2009.

PAULINO, P. V. R.; VALADARES FILHO, S. C.; DETMANN, E.; VALADARES, R. F. D.; FONSECA, M. A.; MARCONDES, M. I. Deposição de tecidos e componentes químicos corporais em bovinos Nelore de diferentes classes sexuais. Revista Brasileira de Zootecnia, Viçosa, MG, v. 38, n. 12, p. 2516- 2524, 2009.

RESTLE, J.; KEPLIN, L. A. S.; VAZ, F. N. Características quantitativas da carcaça de novilhos Charolês, abatidos com diferentes pesos. Pesquisa Agropecuária Brasileira, Brasília, v. 32, n. 8, p. 851-856, 1997.

RIBEIRO, S. S.; VASCONCELOS, J. T.; MORAIS, M. G.; ÍTAVO, C. B. C. F.; FRANCO, G. L. Effects of ruminal infusion of a slow-release polymer-coated urea or conventional urea on apparent nutrient digestibility, in situ degradability, and rumen parameters in cattle fed low-quality hay. Animal Feed Science and Technology, Campo Grande, v. 164, n. 7, p. 53-61, 2011.

RIBEIRO, T. R.; PEREIRA, J. C.; OLIVEIRA, M. V. de M.; QUEIROZ, A. C.; CECON, P. R.; LEÃO, M. I.; ALVARENGA e MELO, R. C. Características da carcaça de bezerros Holandeses para a produção de vitelo recebendo dietas com diferentes níveis de concentrado. Revista Brasileira de Zootecnia, Viçosa, MG, v. 30, n. 6, p. 2154-2162, 2001.

ROMAN, J.; JOBIN, C. C.; RESENDE, F. D.; SIQUEIRA, G. R.; FARIA, M. H.; RIVAS, R. Composição física da carcaça e características da carne de bovinos de corte terminados em confinamento com diferentes dietas. Arquivo Brasileiro de Medicina Veterinária e Zootecnia, Belo Horizonte, v. 62, n. 6, p. 1430-1438, 2010.

SANTOS, A. P.; BRONDANI, I. L.; RESTLE, J.; MENEZES, L. F. G.; OLIVEIRA, L.; SILVEIRA, S. R. L. Características quantitativas da carcaça de novilhos jovens e superjovens com peso de abate similares. Revista Ciência Animal Brasileira, Goiânia, v. 9, n. 2, p. 300-308, 2008.

STATISTICAL ANALYSIS SYSTEM INSTITUTE - SAS. Institute Incorporation. Language Reference. Version 9,4. Cary: SAS Institute, 2001.

TEDESCHI, L. O.; BAKER, M. J.; KETCHEN, D. J.; FOX, D. G. Performance of growing and finishing cattle supplemented with a slow-release urea product and urea. Canadian Journal of Animal Science, Champaign, v. 82, n. 4, p. 567-573, 2002.

VAZ, F. N.; RESTLE, J. Aspectos qualitativos da carcaça e da carne de machos braford superprecoces. Desmamados aos 72 ou 210 dias de idade. Revista Brasileira de Zootecnia, Viçosa, MG, v. 31, n. 5, p. 20782087, 2002. 
Efeito de raça e heterose para características de carcaça de novilhos da primeira geração de cruzamento entre Charolês e Nelore. Revista Brasileira de Zootecnia, Viçosa, MG, v. 30, n. 2, p. 409-416, 2001. 